\title{
DA PSICANÁLISE À NEUROCIÊNCIA: DO FIM AO FIM DA CULPABILIDADE NA DOUTRINA IBÉRICA - UMA VISÃO CRÍTICA
}

Sebástian Borges de Albuquerque Mello

Advogado, Mestre e Doutor em Direito pela UFBA, Professor Adjunto de Direito Penal da Graduação e Pós-Graduação (mestrado e doutorado) da UFBA, Professor de Direito Penal da Faculdade Baiana de Direito.

\section{Resumo}

Diante dos recentes estudos neurocientíficos que apontam a consciência como complexo de reações neurais processadas no sistema límbico, os critérios de atribuição de responsabilidade penal ao indivíduo concreto, notadamente a culpabilidade, passam a sofrer os reflexos desta nova teoria, uma vez que a responsabilidade individual será fundamentada em outros suportes, distintos da ideia de liberdade. $O$ presente trabalho, portanto, propóe discutir as repercussóes das descobertas neurocientíficas dentro de um sistema normativo e de responsabilidades firmados na idei de que o comportamento humano é fundado na liberdade individual. Para tanto, será abordado no primeiro capítulo o conceito de culpabilidade material, fundamentado no "poder atuar de outro modo" e as críticas do finalismo à referida teoria, seguido de uma abordagem em torno da suposta insustentabilidade de um Direito Penal fundado na culpabilidade, sustentada por Gimbernat Ordeig. Diuscute-se, em seguida, a possibilidade de alteração de paradigma para imposiçáo da pena, substituindo a culpabilidade pela ideia de necessidade da pena. Ao final, são abordadas as características da nova teoria neurocientífica sobre o processo de tomada de decisão do homem e sua possível interferência na atual formulação da culpabilidade material.

\section{Palavras-chave}

Direito Penal; Culpabilidade; Neurociência.

\section{Resumen}

Los recientes estudios neurocientificos identifican la conciencia como un conjunto de complejas reacciones neuronales procesadas en el sistema límbico. Eso cambia los criterios de adjudicación de la responsabilidad penal a la persona concreta, sobre todo la 
culpabilidad, sufriendo las consecuencias de esta nueva teoría, ya que la responsabilidad individual será basada en otros medios, distintos de la idea de libertad. Por tanto, este estudio tiene como objetivo analizar el impacto de los hallazgos neurocientificos dentro de un sistema de responsabilidades establecidas en la idea de que el comportamiento humano se basa en la libertad individual. Para ello, será cubierto en el primer capítulo el concepto de material de culpabilidad, basado en el "poder para actuar de otra manera" y la crítica de la finalidad a que la teoría, seguida de una aproximación en torno a la supuesta insostenibilidad de un derecho penal basado en la culpa, sostenida por Gimbernat Ordeig. En seguida, se discute la posibilidad de cambio de paradigma para la imposición de una pena, cambiando de la idea de culpabilidad pela prevención a partir de criterios neurológicos. Al final, se abordan las características de la nueva teoría de la neurociencia sobre el proceso de toma de decisiones del hombre y su posible interferencia en la actual culpabilidad material de formulación

\section{Palabras clave}

Derecho Penal; Culpabilidad; Neurociencia.

\section{Introdução}

Há pelo menos dois séculos o Direito Penal convive com as discussóes sobre livre arbítrio e determinismo. Desde a conhecida luta das Escolas no Século XIX, a liberdade humana ocupa posiçáo central como fundamento dos comportamentos humanos, seja para confirmar, negar ou até mesmo assumir uma postura agnóstica em relação ás capacidades de atuação alternativa do ser humano.

No Século XX, a discussão, no âmbito jurídico-penal, centrava-se sobretudo na construção do conceito de injusto pessoal e a concepção material de culpabilidade formulada por Welzel e sua Teoria Finalista da ação, que concebia o fundamento da censura pessoal do autor na ideia de "poder atuar de outro modo", fundado na concepção de liberdade examinada sob os aspectos antropológico, caracterológico e categorial.

Ocorre que as questóes erigidas como centrais pelo finalismo estão em crise. No âmbito jurídico, o finalismo vem perdendo espaço para concepçóes funcionalistas de Direito Penal, em que a ideia de liberdade vem sendo paulatinamente substituída pela concepção de motivabilidade, sendo esta o fundamento da imposição da pena a um indivíduo concreto. A concepção sobre o "poder atuar de outro modo", alicerce da culpabilidade finalista, vem sendo substituído por uma posição agnóstica, em que a liberdade de decisão deixa de ocupar o centro das discussôes em matéria de culpabilidade.

Se, no âmbito jurídico, a liberdade finalista vem, pouco a pouco, sendo superada, a neurociência traz novas contribuições que podem reformular por completo aquilo que tradicionalmente se compreende como sendo culpabilidade. 
Novos estudos neurocientíficos têm posto em dúvida até mesmo os fundamentos de um conhecido dualismo cérebro-mente, em que a consciência acaba sendo concebida como um complexo de reaçóes neurais processadas no sistema límbico, concepção que poderia modificar por completo todo o sistema de atribuiçáo de responsabilidade pessoal a um indivíduo concreto.

Se torna fácil, portanto, atribuir à descobertas neuriocientíficas o "fim” da culpabilidade, em que a responsabilidade individual será fundamentada em outros suportes, distintos da ideia de liberdade.

No entanto, cumpre asseverar que a neurociência terá dificuldades em encontrar o correlato cerebral da responsabilidade, pois esta é uma atribuição social que se faz a pessoas, e não a processos cerebrais. Este trabalho, portanto, propóe discutir as repercussóes das descobertas neurocientíficas dentro de um sistema normativo e de responsabilidades firmados na ideia - constitucionalmente assegurada, inclusive - de que o comportamento humano é fundado na ideia de liberdade.

Para tanto, será abordado no primeiro capítulo o conceito de culpabilidade material fundamentado no "poder atuar de outro modo" e as críticas do finalismo à referida teoria. No segundo capítulo será tratada a suposta insustentabilidade de um Direito Penal fundado na culpabilidade, sustentada por Gimbernat Ordeig, passando a tratar, no capítulo subsequente, da possibilidade de alteração de paradigma para imposição da pena, substituindo a culpabilidade pela ideia de necessidade da pena. Por fim, discute-se acerca das novas teorias neurocientíficas do processo de tomada de decisão do homem e sua possível interferência sobre a atual formulação da culpabilidade.

\section{0 "Poder Atuar de Outro Modo" e as Críticas ao Finalismo}

Não são poucas as teses que consideram a culpabilidade um conceito que parte de premissas indemonstráveis, e por esta razão constituem um conceito desnecessário para o Direito Penal. Na última metade do século XX, quando se faz referência a "premissas indemonstráveis", quer se tratar, sobretudo, do fundamento material da culpabilidade como "poder atuar de outro modo", a partir da concepçáo finalista de culpabilidade.

O conceito de ação, para o finalismo, funda-se nas estruturas lógico-objetivas e possuem como componentes ônticos a capacidade de atuar de modo final, em que o ser humano é responsável na medida em que pode dirigir sua atividade de modo consciente a uma meta, trazendo consigo a capacidade de obrigar-se ético-socialmente. A estrutura final da ação e a capacidade de autodeterminação conforme sentido são estruturas lógico-objetivas da condição de pessoa, que devem ser observadas e respeitadas pelo Direito (GRACIA MARTÍN, 2004). 
Com base nessa concepção, Welzel (2004) conceitua culpabilidade como a falta de autodeterminação conforme o sentido em um sujeito que era capaz de tê-la. Não é a decisão em si mesma, mas sim o fato de o ser humano deixar-se arrastar por impulsos contrários ao valor. Portanto, a culpabilidade não seria uma livre decisão em favor do mal; ela consiste no fato do sujeito deixar-se prender pela coaçáo causal dos impulsos, sendo capaz de determinar-se conforme o sentido. Conclui, entáo, que a culpabilidade não é um ato de livre autodeterminação, senão precisamente a falta de uma decisão conforme o sentido em um sujeito responsável.

O posicionamento finalista, soberano na doutrina penal desde o pós-guerra até fins da década de 60, trouxe significativas modificaçóes na culpabilidade normativa, notadamente pelo fato de ter excluído todos os objetos de valoração do conceito de culpabilidade, o qual passou a ser, efetivamente, um juízo de valor, representado pela ideia de reprovabilidade.

Os principais questionamentos à culpabilidade definida pelo finalismo não foram centrados no deslocamento do dolo ou da imprudência para o tipo de injusto, nem tampouco pela definiçãao dos elementos da culpabilidade normativa, que, com maiores ou menores variaçôes, firmaram-se como sendo a imputabilidade, a possibilidade de conhecimento do injusto e a exigibilidade de outra conduta. Os aspectos formais da culpabilidade finalista foram adotados pelo pensamento penal que o sucedeu. Pode-se dizer que a culpabilidade formal pós-finalista evoluiu a partir daquela estruturada por Welzel.

$\mathrm{Na}$ verdade, as criticas à concepção finalista de culpabilidade surgem pelo paradigma hermético da sua construção dogmática, alheia à política criminal e, sobretudo, no fundamento da culpabilidade: a liberdade de agir conforme o sentido, que termina no conceito de poder atuar de outro modo.

Hassemer (1994, p. 44) refere que a Teoria Final da Ação teria entrado em jogo com um saber homogêneo sobre o núcleo do Direito Penal - ação, antijuricidade e culpa assentada sobre o "ser", sobre a "natureza das coisas", fazendo com que o pensamento jurídico-penal estivesse concentrado em fundamentos teóricos e na solidificação hermética dos enunciados científicos. Isto representava, para Hassemer, um "veneno" para qualquer relevância político-criminal deste tipo de ciência ${ }^{1}$. Argumenta, então, que o finalismo não estava equipado para uma abordagem político-criminal, na medida em que não teria preocupação com os dados empíricos da realidade sancionatória nem sobre o controle das

1 Em sentido contrário, ressaltando o conteúdo garantidor da estrutura ontológica das coisas, MINAHIM e COELHO, apontam que "O esvaziamento dos conceitos consiste, no campo do Direito, em retirar de certos seres propriedades que constituem sua essência, permitindo entäo um tratamento jurídico diferenciado daquele que lhe seria dado caso essa propriedade fosse reconhecida porque ela simboliza um valor que se deve preservar"(MINAHIM, COELHO, 2007, p.106). 
condutas desviantes. Conclui que se estabelece um impasse insuperável entre finalismo e política criminal, na medida em que esta se baseia na capacidade e disposição de compromisso entre os contendores, enquanto aquele firma suas convicçóes na "essência imutável das coisas".

Desde a década de 60 do século XX, quando as bases da teoria normativa pura já tinham sido acolhidas pelos Tribunais na Alemanha, já se buscava uma alternativa, no campo doutrinário, à tese de liberdade de Welzel e o seu "poder atuar de outro modo". São conhecidas, no aspecto, as críticas de Engish, na sua conhecida obra Die Lehre von der Willensfreiheit in der strafrechtsphilosophischen Dokrin der Gegenwart, na qual sustenta ser impossível provar empiricamente o livre-arbítrio welzelniano, base do juízo de reprovação da teoria normativa da culpabilidade. Hassemer (1994, p. 46) também faz referência às conhecidas críticas de Engish ao finalismo, sendo que este último questionava: "onde termina e começa a estrutura do Ser e onde se insere o foco da valoraçâo?", indagando, também, quais os critérios mediante os quais é possível decidir, na constatação da "natureza pessoal" do ser humano, o que deveria ser creditado na conta da realidade preexistente ou na conta da valoração jurídica.

Em relação às críticas de Engish, Welzel (2004) elaborou um estudo dirigido a respondê-las, reafirmando sua tese de que o homem é livre e será culpável na medida em que dirigiu sua vontade para o injusto, quando poderia fazê-lo de modo distinto.

Baratta (1985, p. 14) afirma que, no plano técnico-jurídico, a construção dogmática de Welzel poderia acarretar um círculo vicioso, na forma assim descrita:

Depois da sistematização dada por Welzel ao desenvolvimento da concepção normativa da culpabilidade, restava por resolver o seguinte problema: se a culpabilidade é a censura pela determinação subjetiva do comportamento, como escapar do ciclo vicioso, no qual o fato de que a determinação subjetiva do comportamento seja valorada negativamente - segundo o disposto por uma norma -, resulta considerado como o critério mesmo dessa valoração? E como precisar um referente objetivo de juízo sem aceitar o princípio ontológico e metafísico da livre vontade, baseado na hipótese de "ter podido atuar conforme a norma", que constitui uma circunstância real, a qual, como atualmente está demonstrado, não é verificável empiricamente depois de que já se tenha realizado o comportamento ilícito e que, em todo caso, não verificável dentro dos limites heurísticos do processo penal?²

2 No original: "Después de la sistematización dada por Welzel al desarrollo de la concepción normativa de la culpabilidad, quedaba por resolver el siguiente problema: si la culpabilidad es la reprochabilidad por la determinación subjetiva del comportamiento, ¿cómo escapar al círculo vicioso en el cual el hecho de que la determinación subjetiva del comportamiento sea valorada negativamente-según lo dispuesto por una norma-, resulta considerado como el criterio mismo de esa valoración?, y ¿cómo precisar un referente objetivo del 
No âmbito mais específico dos fundamentos da culpabilidade, Montes Huapaya (2007) menciona três aspectos polêmicos sobre o posicionamento finalista: a) a ideia de livre-arbírtio; b) o paradigma de inexigibilidade; c) o caráter moralizante da expressão reprovabilidade.

Com relação ao livre-arbítrio, manteve-se a crítica sobre a difícil, quiçá impossível, verificação empírica da possibilidade de alguém atuar dessa ou daquela maneira. A irrepetibilidade da experiência humana faz com que não disponha o juiz de elementos para auferir se o sujeito, no momento da conduta, atuou de forma livre ou não (MELLO, 2010b). Roxin (2003, p.799) assevera que esta concepcção fracassa porque, nem sequer sobre o pressuposto de uma libedade de decisão teoricamente concebível, um "poder atuar de outro modo" do sujeito individual no momento do fato seria suscetível de constatação científica. Na mesma linha de raciocínio, pondera Günther (1998, p.79):

Não é, entretanto, muito claro o que se deva entender afinal por esta "liberdade". Não se deve acolher que possa derivar daquilo que se fizesse presente na pessoa individual no momento do fato, de modo que esta estivesse realmente consciente acerca de uma determinada alternativa de conduta fiel ao direito e fosse capaz de compreendê-la. A liberdade de agir de outro modo é, portanto, uma ficção, que se orienta pelo próprio entendimento dos demais membros da sociedade.

Em face da dificuldade de se estabelecer e demonstrar empiricamente a própria existência do livre-arbítrio, termina o finalismo por ser criticado pelo seu paradigma de liberdade. Com efeito, não obstante o "poder atuar de outro modo" tenha o escopo de buscar essas possibilidades no homem concreto, ele acabou, nos tribunais da então Alemanha Ocidental, sendo adotado a partir de critérios normativos generalizadores, que transformam o poder atuar de uma pessoa específica na suposição do poder atuar de uma pessoa média, com base na experiência.

De acordo com Montes Hupaya (2007) , quando o "poder atuar de outro modo" chegou à ideia do homem médio, com o emprego de presunçôes generalizadoras, inutilizou-se a essência do juízo de imputação individual que constitui a culpabilidade. Por fim, a ideia de que culpabilidade é reprovabilidade, desprovida de um substrato jurídico material, termina por trazer à culpabilidade estampas de natureza moral, religiosa e metafísica que distorce a natureza jurídica do juízo de censura.

Figueiredo Dias (2007, p. 516-517) critica o poder atuar de outro modo sobre um duplo aspecto: a) sua indemonstrabilidade; e b) sua insustentabilidade político-criminal.

juicio sin aceptar el principio ontológico y metafísico de la libre voluntad, basado en la hipótesis del "haber podido obrar conforme a la norma", que constituye una circunstancia real, la cual, como actualmente está demostrado, no es verificable empíricamente después de que se ha realizado el comportamiento ilícito y que, en todo caso, no verificable dentro de los límites heurísticos del proceso penal?”(BARATTA, 1985, p. 14.) 
No que tange ao primeiro aspecto (indemonstrabilidade), sustenta que o "poder agir de outro modo" seria possível somente quando fosse viável comprová-lo não apenas numa vertente teorética, de se saber "se" em geral existe o referido poder, mas também numa linha prática de se saber "quando" e "em que medida" se verifica a capacidade real de uma pessoa concreta. Afirma que as correntes do livre-arbítrio radicam sua tese numa visão abstrata do homem típica do século XIX, como sendo o homem um senhor absoluto de seu mundo, com base numa psicologia e sociologia incipientes, as quais hoje têm consciência da impossibilidade de responder sobre o "se", "quando" e "quanto" acerca do livre-arbítrio. Logo, apenas a antropologia filosófica e a ontologia (que cuidam do pensamento fundamental sobre o existir humano) poderiam responder a tais questóes, mas a preocupação atual dos referidos campos do conhecimento refere-se muito mais à liberdade como característica do ser que age, e não à liberdade do ato em si mesmo. Conclui, então, que a capacidade de poder agir de outro modo é inverificável e náo pode ser avançada de maneira responsável, pois é alicerçada numa visão oitocentista.

Em relação às consequências político-criminais, asserte que todas as vezes que um réu no processo alegar não ter podido agir de outro modo e não for possível provar o contrário (sustentando ser impossível a prova em sentido contrário), a consequência deverá ser forçosamente a absolvição, em face dos princípios da presunção da inocência e do in dubio pro reo. Isto traria, portanto, consequências insuportáveis para o sistema.

Córdoba Roda (1997, p.53) também sintetiza as críticas à culpabilidade finalista, centrada em dois aspectos distintos:

a) na impossibilidade prática de que os tribunais deem efetiva constância à liberdade de atuaçáo do condenado na situaçáo concreta em que cometeu o delito submetido a juízo; b) nas dificuldades de conceber a culpabilidade como uma censura, quando o certo é que a formulaçáo desta não pressupóe a existência da autocensura no agente. $\mathrm{O}$ caracterizar a culpabilidade como um juízo que não aparece condicionado nem à positiva constatação de uma liberdade de atuar de modo distinto do sujeito, nem a um sentimento de censura neste, constitui um sério obstáculo para conceber a essência da pena como um castigo de uma determinada conduta ${ }^{3}$.

$\mathrm{Na}$ linha do que pondera Busato (2011, p.47), a crise em que se encontra o princípio da culpabilidade tem íntima relação com a impossibilidade ou dificuldade de comprovar

3 No original: "a) en la práctica imposibilidad de que los tribunales den efectiva constancia de la libertad de actuación del condenado en la situación concreta en que la cometió el delito sometido a juicio; b) en las dificultades de concebir la culpabilidad como un reproche, cuando lo cierto es que la formulación de éste no presupone la existencia de autorreproche alguno en el agente. El caracterizar a la culpabilidad como un juicio que no aparece condicionado ni a la positiva constatación una libertad de actuar de modo distintivo en el sujeto, ni la de un sentimiento de reproche en éste, constituye un serio obstáculo para concebir le esencia de la pena como un castigo de una determinada conducta". (CÓRDOBA RODA, 1977, p. 53). 
o poder atuar de outro modo, isto é, poderia ter atuado em conformidade ao ordenamento jurídico quando não o fez. De igual modo, há também a impossibilidade de se identificar "as condicionantes empiricas que incidem sobre a atuação criminosa do sujeito e em que medida elas são determinantes desta atuação".

Diante de tantas críticas ao conceito de culpabilidade como "poder atuar de outro modo", sobretudo sobre as dificuldades de demonstração empírica do chamado "poder atuar de outro modo", náo seria de se estranhar o surgimento de correntes de pensamento que, em vez de substituir o fundamento material da culpabilidade, consideram a culpabilidade, em si mesma, incerta, e, talvez, desnecessária para o Direito Penal contemporâneo.

Com efeito, os questionamentos sobre o fundamento da culpabilidade para o finalismo faz a própria ideia de culpabilidade entrar em crise, que se alastra suas consequências inclusive para a própria dogmática penal. Deste modo, a própria posição da culpabilidade como fundamento da imposiçáo da pena a um indivíduo concreto passa a ser questionada. Pondera Pérez Manzano (1990) para o surgimento de soluçóes do tipo input, em que se reconstrói dogmaticamente o fundamento da culpabilidade, mas também para modelos do tipo output, em que a culpabilidade por ver-se substituída por um elemento estranho, como as finalidades preventivo-gerais e especiais da pena.

Assim, admitindo-se a indemonstrabilidade de que o sujeito poderia atuar conforme o direito naquela situação concreta levaria ao ocaso culpabilidade como fundamento da pena e do direito penal, pois, não sendo possível demonstrar que o sujeito poderia ter agido de outro modo, não seria tampouco possível responsabilizá-lo por sua escolha (BUSATO, 2011).

Atualmente, a missão de garantia intrínseca à culpabilidade se vê submetida a novas tensôes, de tal forma que a procura de um conceito alternativo ao "poder atuar de outro modo" é uma característica comum da dogmática penal do pós-finalismo. Percebe-se, na doutrina penal alemã e espanhola, que o ponto de partida para a discussão sobre a culpabilidade é a crítica ao conteúdo material da culpabilidade em Welzel (MELLO, 2010ª, p.277).

\section{A Tese de Gimbernat Ordeig sobre a Insustentabilidade de um Direito Pe- nal Fundado na Culpabilidade}

Na Espanha, Gimbernat Ordeig (1970) apontou, em 1970, a possibilidade de se abolir a culpabilidade, no seu conhecido escrito “¿Tiene un futuro la dogmática penal?", que se tornou referência obrigatória nos estudos sobre culpabilidade.

O referido autor procura desconstruir a culpabilidade como conceito central em torno do qual se edifica a dogmática jurídico-penal. Na verdade, Gimbernat (1970, p.497) 
considera que os juristas atribuem uma importância excessiva à culpabilidade no âmbito da dogmática jurídico-penal, o que termina pondo em descrédito a pena e a própria categoria científica do Direito Penal.

O ponto inicial de seu questionamento reside naquilo que ele chama de fé irracional e desesperada dos juristas no dogma do livre-arbítrio. Sustenta que tais juristas desprezam qualquer estudo de outras ciências sobre a motivação do comportamento humano e assumem a defesa do livre-arbítrio em bases insustentáveis. Gimbernat (1970), todavia, entende que a defesa desse modelo de culpabilidade consiste numa profissão de fé, numa arrogância dos juristas que não são especialistas em liberdade humana e que desprezam os conhecimentos científicos sobre a matéria. O livre-arbítrio, pondera, não tem respaldo na psicologia e na psicanálise, pois, ainda que em abstrato exista o livre arbítrio, é impossível demonstrar se uma pessoa concreta em uma situação concreta cometeu livremente um determinado delito.

Segundo Gimbernat (1970), essa defesa irracional, a partir de fundamentos que considera indemonstráveis, decorre de um suposto "caos" anunciado pelos mesmos juristas na hipótese de ser rechaçada a culpabilidade como fundamento da pena. A abolição da culpabilidade permitiria a instauração de um Direito Penal autoritário e cruel, vulnerador da dignidade da pessoa humana e apto para funcionar como instrumento de ideologias totalitárias, em que a pena seria imposta com base única e exclusiva na suposta periculosidade do autor da infração.

Isso deriva, segundo sua ótica, do preconceito que esses mesmos juristas possuem em relação a um Direito Penal não fundado na culpabilidade, como se a democracia, a dignidade da pessoa humana e a própria dogmática penal dependessem do princípio de culpabilidade. Não seria a crença ou a descrença na capacidade de autodeterminaçáo do homem que impede o autoritarismo, senáo o respeito à pessoa humana que integra a tradição política de determinados países (GIMBERNAT, 1970).

Por esta razão, Gimbernat (1970) argumenta que a psicanálise, ao colocar em dúvida a culpabilidade do sujeito, não priva o Direito Penal de suas bases, mas sim justifica o Direito Penal prescindindo da ideia de culpabilidade ou livre-arbítrio. Pois, da mesma maneira que a consciência, o superego da criança se forma com a privaçáo de carinho e o castigo diante do comportamento proibido, a sociedade, mesmo sem constatar se o comportamento proibido tem sua origem numa decisáo livre de vontade, tem que recorrer à pena para reforçar aquelas proibiçóes, com o fim de evitar condutas que atacam as bases da convivência social.

A pena é tida como uma "amarga necessidade", um recurso elementar que o Estado dispóe para assegurar a convivência entre os homens. $\mathrm{O}$ reconhecimento de que a pena seja necessária não significa, todavia, que o modelo de responsabilidade fundado na culpabilidade seja igualmente imprescindível. 
Para Gimbernat (1970), o Direito Penal que não se alicerça no livre arbítrio determina a gravidade das penas da mesma maneira que o determinam, em geral, toda as leis penais: 1) em primeiro lugar, pelo valor do bem jurídico protegido; 2) em seguida, castigando com mais severidade os delitos dolosos do que os culposos em relaçáo ao mesmo bem jurídico. A tarefa que a pena tem que cumprir é preventiva, isto é, reforçar o caráter inibidor de uma proibição, criando e mantendo controles sobre os cidadãos, que hão de ser mais rigorosos quanto maior seja a nocividade social de seu comportamento.

Assim, considera que os limites aos excessos punitivos não existem porque o livre -arbítrio seja a base da pena, mas sim porque o legislador deve tentar alcançar uma certa eficácia com este importante meio de política social que é o Direito Penal (GIMBERNAT, 1970). Deste modo, Gimbernat terminou por esboçar as bases de um Direito Penal arrimado na prevenção, e não na culpabilidade (COUSO SALAS, 2006).

A construção teórica de Gimbernat se arrima na necessidade preventiva da pena, dispensando a culpabilidade, na qual se busca apenas a maior prevenção criminal possível com o mínimo de sacrifício da liberdade individual necessário, de modo que as grandes questóes relativas à culpabilidade serão resolvidas a partir de critérios puramente preventivo-utilitaristas (MELLO, 2010b).

Assim, para Gimbernat, a ideia de culpabilidade pode ser facilmente substituída pela necessidade da pena. E que necessidade é esta? Ele está centrada na necessidade de reforçar a proibiçáo de comportamentos, o que, em outras palavras, pode ser dito como sendo a necessidade de prevenção de novos delitos. É com base na necessidade de inibição de novos delitos que a pena dos crimes dolosos é maior do que nos culposos, que se justifica a irresponsabilidade penal dos inimputáveis.

Logo, conclui Gimbernat a dogmática penal tem futuro, o Direito penal tem futuro, mas não pode dizer o mesmo em relação à culpabilidade fundada na ideia de livre-arbítrio.

Percebe-se, portanto, que Gimbernat termina por tratar a culpabilidade e o livre -arbítrio como conceitos indissociáveis, como se a indemonstrabilidade do "poder atuar de outro modo" sepultasse por completo a ideia de culpabilidade como fundamento da imposição da pena.

Estudos psicológicos e psicanalíticos trariam fundamentos capazes de justificar a imposição de pena, sem que a dogmática penal precisasse recorrer à culpabilidade que, na visão do autor, traria mais problemas do que soluçóes para o Direito Penal.

\section{A Mudança de Paradigma e a Ideia de Motivabilidade como Fundamento da Culpabilidade}

O posicionamento de Gimbernat Ordeig é constantemente referido como paradigma da desconstrução do conceito de culpabilidade fundada no livre-arbítrio. Ele anunciou o 
fim da culpabilidade como pilar em que se ergue a dogmática jurídico-penal, valendo-se de estudos de psicanálise e psicologia para desconstruir o conceito finalista. No entanto, não é possível vislumbrar, a partir de tais estudos, fundamentos suficientemente coerentes para justificar a imposição da pena a um indivíduo concreto.

De fato, há de se reconhecer que a psicanálise traz questionamentos inquestionáveis à concepção de "poder atuar de outro modo", pois a consciência não é soberana e o "eu" não é autônomo. Com efeito, a psicanálise faz com que os registros do "eu" e da consciência sejam apenas uma modalidade do ser (BIRMAN, 1970). Mas, a partir da psicanálise, não se consegue, de modo satisfatório, um instituto capaz de substituir a culpabilidade, pelo menos segundo o entendimento esposado por Gimbernat.

Cerezo Mir (2005), adepto ao posicionamento finalista, considera que o abandono do princípio da culpabilidade não permite que se mantenham intactas suas consequências, nem consegue justificar satisfatoriamente situações tradicionalmente resolvidas pela culpabilidade, como a ocorrência de erro de proibição invencível, a aplicação de medida de segurança aos inimputáveis e o problema dos crimes qualificados pelo resultado.

Córdoba Roda (1977), na mesma linha, sustenta serem dois os principais inconvenientes em se substituir a culpabilidade pela necessidade da pena: o primeiro deles diz respeito a uma incapacidade para oferecer uma determinação conceitual de certas matérias, como inimputabilidade e erro de proibição; o segundo problema está no risco que posicionamentos preventivos podem acarretar para algumas garantias inerentes à pessoa humana. Assim, considera que as necessidades preventivas seriam uma garantia adicional, mas jamais poderiam substituir a culpabilidade.

Além da dificuldade em se justificar determinados institutos prescindindo-se da ideia de culpabilidade, também não há clareza no pensamento de Gimbernat sobre de que maneira as ideias extraídas da psicologia e psicanálise poderiam estabelecer uma uniformidade sistemático-preventiva para justificar institutos até então tratados pela culpabilidade. Ao recorrer à psicologia e à psicanálise, reforçando o caráter intimidador da pena, Gimbernat termina por justificar e fundamentar a pena numa espécie de prevenção geral intimidatória. No entanto, quando se refere a situaçóes em que alguns crimes são punidos distintamente em face da comoção social gerada, o argumento já parece ter enfoque a partir da prevenção geral positiva.

Segundo Couso Salas (2006), não resta claro, no pensamento de Gimbernat, qual é efetivamente o substrato da capacidade intimidatória da pena, capaz de motivar, ou melhor, inibir a prática de novos delitos. Em determinados momentos, tal capacidade inibitória se mostra, ora como substrato psicológico descritivo, ora como substrato normativo, o que acarreta uma certa ambivalência sobre qual a concepção de prevenção geral a ser adotada em caso de supressão da culpabilidade. 
Pérez Manzano, na mesma linha, aduz que Gimbernat, ao referir-se à pena mais grave para o crimes doloso em relação ao culposo, utiliza o argumento de distinta comoção social que produz uma lesão dolosa frente à culposa, ou mesmo no maior transtorno social de uma lesão à vida frente a uma lesão patrimonial. Os argumentos fundados na necessidade a partir de expectativas sociais são argumentos de prevenção geral positiva, e não intimidatória, e uma mudança importante de ponto de vista, pois não se trata de uma diferenciação intrínseca entre as condutas, mas ao valor atribuído pela sociedade a cada uma delas.

A referência de que a pena teria na formação da consciência a mesma função do castigo aplicado pelo pai ao filho não é suficiente para, a partir dos critérios preventivos, justificar de modo homogêneo diversos institutos, como a irresponsabilidade penal de crianças e adolescentes e a diferença da resposta penal a crimes dolosos e culposos. Por esta razão a tese de Gimbernat, apesar de constantemente citada, não vingou e a culpabilidade continuou sendo o paradigma da imposição da pena, embora com outros fundamentos.

Diante das dificuldades em se conseguir no paradigma finalista tradicional o fundamento material da culpabilidade, buscou-se na ideia de motivação uma alternativa ao "poder atuar de outro modo" como forma de se justificar a imposição da pena a um indivíduo concreto.

Ressalte-se que a normalidade de motivação não é uma questão recente na doutrina da culpabilidade. A ideia de motivação normal como fundamento material da culpabilidade está presente na origem do pensamento normativista, quando Frank (2004) e Goldschmidt (2002), nas suas respectivas concepçóes normativas de culpabilidade, utilizaram a ideia de normalidade de motivaçáo como requisito material do juízo de censura que consistia a culpabilidade no início do século XX.

Buscou-se, na verdade, uma substituição do conceito de "poder atuar de outro modo" pela aptidão do sujeito para compreender e ser motivado pelas normas jurídicas. O elemento fundante da culpabilidade passaria a ser o fato do sujeito possuir a possibilidade real de ser motivado pelo comando normativo (BUSATO, 2011).

Segundo Pérez Manzano (1990, p. 115), a ideia de capacidade de motivaçáo como fundamento material da culpabilidade iniciou-se na Alemanha com o pensamento de Danner, que substituiu o conceito finalista de "liberdade de eleição" pela "possibilidade de eleição", que significava, por seu turno, uma normalidade de motivação. Na Espanha, a culpabilidade material entendida como capacidade de motivação foi acolhida, entre outros, por Muñoz Conde e por Mir Puig.

A capacidade de motivar-se conforme as normas, no pós-finalismo, não é corolário de uma postura indeterminista fundada no livre-arbítrio. Trata-se de uma espécie de relação que se estabelece entre o sujeito e a norma, a partir da qual se verifica a possibilidade 
de o sujeito motivar seu comportamento a partir dos parâmetros fornecidos pelas normas jurídico-penais.

A motivabilidade, então, passa a ser utilizada como fundamento material da culpabilidade, em substituição ao "poder atuar de outro modo", e se abandona a tese do livre-arbítrio como pressuposto da culpabilidade. Embora náo seja necessariamente decorrência de uma postura filosófica determinista, a citada corrente de pensamento permite que construçóes doutrinárias neste sentido sejam elaboradas.

No aspecto, Mir Puig claramente adota um posicionamento determinista na sua construção dogmática da culpabilidade; Muñoz Conde parece adotar uma postura agnóstica. Em suma, a noção de motivabilidade não se vincula obrigatoriamente a uma posição em relação ao mais tormentoso dilema - ainda longe de soluçáo - sobre o problema da liberdade humana (MELLO, 2010b).

A despeito de partirem de premissas filosóficas distintas quanto ao problema do determinismo e do indeterminismo, os pensamentos de Muñoz Conde e Mir Puig assemelham-se inicialmente pelo rechaço ao fundamento material da culpabilidade finalista. Mas não é só: há similitudes - mas não identidade - na elaboração de uma culpabilidade relacionada estreitamente com as finalidades preventivas da pena, bem como nos limites demandados por um Estado de Direito, pluralista, social e democrático.

A ideia de motivabilidade surgiu como uma alternativa ao "poder atuar de outro modo", em que a ideia de livre-arbítrio, tida como indemonstrável, seria substituída pela capacidade de motivação normativa. O culpável seria aquele capaz de reagir diante do comando normativo, isto é, aquele capaz de se motivar pelo conteúdo da norma.

$\mathrm{Na}$ verdade, a tese de que o motivável tem maior possibilidade de evitar o delito, quando comparado com o não-motivável, é um dado empírica e estatisticamente discutível, que terminaria na mesma imprecisão teórica do "poder atuar de outro modo". Carbonell (1996) sustenta que motivabilidade possui os mesmos problemas que pretende supostamente resolver, pois a afirmação de que um sujeito cometeu um fato ilícito quando podia e devia motivar-se pela norma, mas não o fez, equivale a dizer que o sujeito podia e devia levar a cabo um comportamento distinto daquela que o mesmo efetivamente atuou, o que significa dizer que o homem é livre para decidir se prosseguia ou não com a conduta contrária à norma.

Busato (2011, p. 55), na mesma linha, considera a substituição do livre arbítrio pela capacidade normal de motivação uma verdadeira "fraude de etiquetas". Com efeito, o elemento fundante da culpabilidade pressupóe a norma como determinaçáo e que, por muito ajustada ao finalismo, "deixa à margem, toda a perspectiva de norma como valoração, especialmente, os efeitos críticos deste reconhecimento". Por isso considera que este posicionamento, na medida em que persiste - assim como no finalismo - em assumir a tarefa de 
conformaçáo da atitude interna das pessoas, em nada difere da ideia de reprovabilidade, pois "o fundamento de reprovaçâo, baseado na 'possibilidade de atuar de outra maneira', significa, exatamente, o mesmo que a lcapacidade de motivar-se normativamente".

Nesse sentido se dirige a crítica de Cobo del Rosal e Vives Antón (1999, p. 451), para quem a capacidade de motivação é táo pouco comprovável quanto o livre-arbítrio. Além disso, dizem não compreender bem, "[...] sobre uma também genérica motivabilidade normal possa fundar-se um castigo. Pois o castigo pressupóe uma censura pessoal que cabe ao autor da infração por tê-la cometidó.

Pérez Manzano (1990, p.128), no aspecto pondera que a ideia de motivaçáo defendida pelos motivacionistas espanhóis pretendem não apenas solucionar a questão do livre-arbítrio, mas também excluir o caráter de censura do juízo de culpabilidade e a ideia de retribuiçáo. No entanto, considera que a ideia de motivabilidade é uma teoria sobre o conteúdo material de culpabilidade que pode servir a distintas finalidades: a) para excluir a culpabilidade tradicional e fundamentar o princípio da necessidade da pena; b) para reformular o conteúdo da culpabilidade dentro de sua funçáo de limite das necessidades preventivas; c) como reinterpretação do "poder atuar de outro modo". No entanto, a referida autora pondera:

Por outro lado, a possibilidade de demonstrar empiricamente a possibilidade de motivação de um autor concreto numa dada situação num processo penal é táo duvidosa quanto demonstrar a possibilidade de demonstrar o poder atuar de outro modo. Portanto, a teoria da motivação não fornece uma solução original para o problema de da forma de sua determinação, pois recorre também de uma presunção normativa - todos os normais são motiváveis ou todos os não normais são imotiváveis- e ao juízo comparativo tendo como base o homem médio ${ }^{5}$

Mir Puig (2004) chega a contestar essa tese, sustentando que o sujeito é penalmente responsável não porque tem capacidade normal de motivação, no sentido em que poderia haver-se motivado a si mesmo (porque isso implicaria o reconhecimento da liberdade de vontade), mas sim porque o sujeito pode ser motivado pela norma, no sentido passivo. Para Mir Puig, motivação não é uma capacidade ativa de o sujeito motivar-se, mas sim a

4 No original: "sobre una también genérica motivabilidad normal pueda fundarse un castigo. Pues el castigo supone un reproche personal que se hace al autor de la infracción por haberla cometido." (COBO DEL ROSAL, Manuel; VIVES ANTÓN, Tomás S. 1999, p. 541).

5 No Original: "Por otro lado, la posibilidad de demostrar empiricamente la posibilidad de motivación de un autor concreto en un una determinada situación en un proceso penal es tan dudosa como la posibilidad de demostrar el poder actuar de modo distinto. Por ello, la teoría de la motivación no aporta una solución original al problema de la forma de su determinación, pues se acuda también a una presunción normativatodos los normales son motivables o todos los no normales son inmotivables - y al juicio comparativo respecto del hombre medio" 
capacidade de ser passivamente influído pelas normas, em que a motivação consiste num complexo de forças causais motivadoras percebidas pelo sujeito.

A despeito das justificativas de Mir Puig (2004), é possível encontrar um mesmo viés generalizante que lembra o já criticado barema do "homem médio", que, em Mir Puig, parece ser substituído pelo paradigma do "homem normal", que seria uma ficção tão indemonstrável quanto o próprio livre arbítrio, e que poderia ceder espaço ao arbítrio, notadamente numa sociedade pluralista, em que as características do homem "normalmente motivável" podem variar de acordo com inúmeras circunstâncias, e por isso que Mir Puig recorre a critérios extrínsecos ao próprio conceito de culpabilidade, como a justiça e aos princípios do Estado Democrático de Direito para limitar as funçôes preventivas do Direito Penal.

\section{0 Novo Viés Interpretativo Dado pelas Neurociências}

A Escola Positiva no Século XIX considerava a ideia de livre arbítrio como um pressuposto metodológico errôneo e anticientífico, porque a liberdade rompe a série causal que une os fenômenos entre si. Em outras palavras, a ideia de um ato livre representa uma ruptura, um hiato entre as relaçóes causais que se manifestam de maneira ininterrupta no universo (BOTTIOL, 1977). Com isso, a antropologia e a sociologia criminal surgem como forma de explicar os fenômenos causais que determinam o comportamento humano.

De igual modo, como visto, Gimbernat Ordeig, na segunda metade do Século XX, também apontou razóes para descartar a incidência do livre arbítrio, sustentando que as descobertas psicanalíticas fariam sucumbir o livre-arbítrio como base de uma teoria da culpabilidade.

No último quarto do Século XX, estudos de neurociência mais uma vez póem em xeque os processos decisórios tidos como racionais e conscientes. Experiências conduzidas por neurocientistas abriram portas para novas descobertas: o cérebro indica determinadas tomadas de decisóes humanas, antes mesmo de que a pessoa tenha consciência de que decidiu desta ou daquela maneira. Em outras palavras, neurocientistas demonstraram que a decisão sobre o agir humano acontece no inconsciente muito antes da pessoa viver conscientemente o impulso (LIBET, 2004).

Surgem, portanto, correntes de pensamento que se rendem de imediato às novas concepçóes, sob o argumento de que o homem deve render-se à ciência, e, por esta razão, negar por completo a ideia de liberdade de ação, e, por consequência, modificar por completo os fundamentos de imposição de pena a um indivíduo concreto.

\subsection{Os Postulados da Neurociência}

Há uma conhecida metáfora freudiana segundo a qual Copérnico, Darwin e o próprio Freud seriam responsáveis por três grandes feridas narcísicas da humanidade. Copérnico, ao 
desenvolver o heliocentrismo, sustentando que o mundo em que vivemos não é o centro do universo, mas apenas mais um entre tantos outros que giram em torno do sol; Darwin, por demonstrar que o ser humano não é uma espécie diferenciada, mas sim uma entre tantas outras que evoluíram a partir de um ancestral comum, a partir da seleção natural; Freud, por sua vez, é responsável pela última ferida, ao suscitar que a consciência é a menor parte e a mais fraca da vida psíquica, existindo uma série de fatores náo conscientes que demonstram que "o 'eu' não é senhor em sua própria casa (FREUD, 1996)".

Deste modo, uma das marcas do Século XX foi a descoberta de processos mentais inconscientes a partir de estudos da psicologia e da psicanálise. A neurociência trouxe uma contribuição adicional - e para seus defensores, decisiva - sobre a questão do livre-arbítrio e os processos decisórios que motivam as condutas humanas.

Na conhecida obra $O$ erro de Descartes, aponta Damásio para o que considera um equívoco na concepção cartesiana de que o pensar e a consciência de pensar seriam os verdadeiros substrato do existir. Com efeito, para Damásio (2012), antes do aparecimento da humanidade, os seres já eram seres, que evoluímos até o surgimento da humanidade e aquilo que se chama de consciência. Deste modo, a existência precede o pensamento, e que o pensamento consciente é causado pelas estruturas e operaçôes do ser.

Essa é a dimensão com a qual o direito se depara: a descoberta de que a maior parte daquilo que cada pessoa faz ou sente não está sob o seu controle consciente. A consciência é apenas a menor parte daquilo que revela o cérebro, e a maioria das operaçóes cerebrais - inclusive algumas daquelas relacionadas a tomada de decisóes - está acima do espaço da mente consciente. $\mathrm{O}$ cérebro é visto como um órgão que toma decisóes sem que nossa consciência perceba. Na linha do que pondera Eagleman, "o cérebro faz suas maquinaçóes em segredo, conjurando ideias como uma magia tremenda. Ele não permite que seu colossal sistema operacional seja sondado pela cogniçáo consciente. O cérebro cuida de seus negócios incógnito" (EAGLEMAN, 2012, p.15).

Nessa ordem de ideias, a neurociência terminaria por concluir que todos estados e processos mentais são causados por processos neurobiológicos que têm lugar no cérebro, como um verdadeiro conjunto de processos físicos, químicos e mecânicos que estão sendo desvendados e descobertos por intermédio do mapeamento do cérebro.

Em suma, a neurociência fez ganhar força novos defensores do determinismo, em que, a partir dos estudos de Libet, entendem que todo comportamento humano esteja condicionado pelo funcionamento neurofisiológico do cérebro humano. E nessa linha de raciocínio, isso termina por reafirmar a crise de culpabilidade com concepçôes fundadas no livre-arbítrio, pois, sendo o cérebro um órgão físico, sujeito a regras da física, não teria espaço para a ideia metafísica de livre-arbítrio. O cérebro, regido por regras físico-químicas, é considerado como parte do próprio corpo, de modo que emoçóes, pensamentos, 
sensaçôes e sentimentos nada mais são do que processos causais, não sendo possível dissociar o "eu" consciente da própria estrutura física em que ele se localiza.

Demetrio Crespo (2013) faz referências ao que chama de bases de um "neurodeterminismo", que possuem como característica central a contrariedade à ideia de liberdade de vontade, citando, como exemplos:

a) Wolf Singer entende que processos construtivos formam aquilo que vem a ser a conduta humana. Cada ação corresponderia por uma combinação entre a constelaçáo que forma o estímulo atual e os estados cerebrais imediatamente anteriores, e que ditos estados cerebrais estão determinados pela organizaçáo genética previamente dada pelo sistema nervoso.

b) Gerhard Roth, para quem a representação tradicional pela qual a vontade se transforma em atos concretos dirigidas por um "eu" consciente não passa de uma ilusão, pois as decisóes, desejos e intençóes ocorrem no sistema límbico alguns segundos antes que possa ser percebida de modo consciente;

c) Wolfgang Prinz compara a liberdade de vontade ao "unicórnio", isto é, uma construção teoria, um produto cultural que não existe na realidade. A liberdade de vontade é tida como uma instituição social que não encontra correspondência com a realidade cientificamente demonstrável do ponto de vista psíquico;

Frisch (2012) pondera que Singer, Roth e Prinz, entre outros, deduziram que há uma incompatibilidade entre teses indeterministas e as investigaçóes neurológicas: com efeito, sustentam que os processos decisórios de cada pessoa estão determinados pelas experiências e modelos de decisão armazenados no cérebro, especificamente no sistema límbico.

A neurociência, portanto, resume o que se chama de livre-arbítrio a um conjunto de processos causais que se processam no sistema límbico, sendo que a suposta consciência de liberdade consistiria numa mera ilusão sem base científica, ficando no mesmo plano metafísico em que se encontram as religióes e a superstição. Nessa linha como pondera Hirsch (2013, p. 44), o sistema límbico seria um "aparato organizado de poder", frente ao qual o ser humano, enganando a si próprio, se situa aparentemente como livre.

Trata-se, portanto, de um nova embalagem para um velho problema: livre-arbítrio e determinismo, e suas repercussóes no juízo que se faz sobre os critérios para a imposição da pena a um indivíduo concreto, que, com maiores ou maiores divergências, se costuma chamar de culpabilidade.

Por essa razão, recentemente tem adquirido relevância determinados estudos que relacionam neurociências com Direito, Direito Penal e culpabilidade, interferindo na 
compreensão sobre a liberdade humana, na concepção de culpabilidade e sobre as finalidades da pena. Isso pode acarretar, na linha do que sustenta Queiroz (2013), uma verdadeira revolução, haja vista que a ideia de liberdade de decisão racional seria uma mera ilusão criada pela mente consciente, pois, para significativa parcela de neurocientistas, as decisóes humanas procedem de processos neurais complexos inconscientes sobre os quais o "eu" consciente: a) ou náo tem poder algum; b) ou tem o mínimo de poder ou influência, já que o cérebro é um órgáo como outro qualquer.

Rubia (2013, p.190) chega a afirmar que "a hipótese de não existência de liberdade parece ser a que melhor se adapta a resultados obtidos experimentalmente até agora". E sendo o sistema penal fundado na ideia de culpabilidade, e esta, por sua vez, construída a partir de um sistema de responsabilidade que toma o homem como ser livre dotado de consciência e vontade para atuar de modo conforme ou contrário ao Direito, a neurociência terminaria por estabelecer o chamado "efeito dominó" a que se referira Gimbernat, e terminar por estabelecer um processo de desmoronamento em cadeia dos sistemas de responsabilidade penal e de justificação do direito de punir.

\subsection{0 "Novo Fim" da Culpabilidade}

A tese neurodeterminista não acarreta o fim do Direito Penal. A história demonstra que muitos defensores de postulados deterministas não propugnaram o fim do sistema punitivo. Frisch considera que, ao estabelecer um modelo determinista de tomada de decisóes e de condutas, o sistema punitivo seria, à semelhança de modelos desenvolvidos por Feuerbach e von Liszt, fundado em coaçôes psicológicas ou de qualquer outro tipo. Deste modo, as sançóes penais seriam aplicadas de modo a condicionar o sistema límbico do autor considerado perigoso (FRISCH, 2012).

A partir das conclusôes neurocientíficas de que "poder atuar de outro modo" é uma fiç̧ão e que cada comportamento humano estaria programado a partir de mecanismos inconscientes decorrentes da genética, de experiências de infância, de hormônios, toxinas ambientais, doenças, neurotransmissores e circuitos neurais, enfim, uma série de circunstâncias que deixaria muito pouco ou praticamente nenhum espaço à ideia de livre-arbítrio ou o conceito de culpabilidade como resultado de uma conduta livre.

Deste modo, soçobram os fundamentos a partir dos quais é possível considerar o homem como responsável pelos seus atos a partir da ideia de livre-arbítrio. De que maneira é possível compatibilizar tais estudos com a culpabilidade? É possível que, mais uma vez, defensores do livre-arbítrio sustentem que um Direito Penal adequado às descobertas neurocientíficas será caótico, totalitário e que desrespeita a dignidade da pessoa humana? Já que existe uma espécie de programação cerebral inconsciente, a questấo novamente estaria no campo da causalidade e da prevenção. 
A neurociência, se levadas últimas consequências no Direito Penal, terminaria por terminar com uma distinção entre condutas voluntárias e involuntárias, bem como modificar completamente a compreensão de conceitos como dolo, conhecimento ou intencionalidade (CRESPO, 2013).

Como sustenta Popper (1975), de acordo com o determinismo, qualquer teoria inclusive a do próprio determinismo, é sustentada em razáo de certa estrutura em que se arrima - e no caso da neurociência, esta estrutura é o próprio cérebro. Nas suas palavras (POPPER, 1975, p. 207):

Consequentemente, estamos nos enganando a nós mesmos (e somos fisicamente determinados a nos enganarmos) sempre que acreditamos que há coisas tais como argumentos ou razóes que nos façam aceitar o determinismo. Ou, em outras palavras, o determinismo físico é uma teoria que, se verdadeira, não é argumentável, visto que como deve explicar todas as nossas reaçôes, inclusive o que nos parecem ser crenças baseadas em argumentos, como devidas a condiçôes puramente físicas.

Há, na verdade, um medo arraigado de se entender que não existe livre-arbítrio. Daniel Dennet (2000), em obra especialmente dedicada ao tema, sustenta que o livre -arbitrio é um desejo do homem na medida em que nós desejamos decidir com sabedoria sobre nossos atos, a partir de suas expectativas e desejos. O determinismo seria aterrador, ao implicar que todos os nossos atos estáo controlados, ou pelo passado, ou por acontecimentos do presente causados por acontecimentos passados que náo controlamos, e não queremos perder o controle nem ser controlados por alguém como se fôssemos marionetes.

Então, a discussão reside sobre a importância e repercussão prática que esta descoberta pode causar na soluçáo dos problemas criminais. De um lado, pode-se sugerir que, já que cada um atuou de acordo com determinada predisposiçáo inconsciente a partir do sistema límbico, não é possível considerar cada pessoa responsável pelos seus atos, a partir do que noçóes como imputabilidade ou culpabilidade restarão inúteis (EAGLEMAN, 2012).

Assim, novamente se decreta o fim da culpabilidade, tida como desnecessária ao desenvolvimento do Direito Penal.

A questão é se o problema do livre-arbítrio é realmente decisivo para que haja um conceito de culpabilidade. Dennet considera que saber ou náo se o sujeito no caso concreto, podia ou não ter atuado de outra maneira supóe a existência de uma curiosidade metafísica particularmente pura, que carece de qualquer motivo ulterior, pois a resposta, qualquer ela que seja, não modificará em nada o transcorrer do mundo (DENNET, 2000). 


\section{Entre Modelos de Culpabilidade. Liberdade e Livre-Arbítrio}

Decretar o fim do livre-arbítrio ou da concepção de "poder atuar de outro modo" como fundamento material da culpabilidade náo é um privilégio da neurociência. Nem é tampouco um privilégio de visóes deterministas.

De fato, há muito a ideia finalista sobre um Direito Penal da culpabilidade tem sido questionada, quiçá superada, pela doutrina jurídico-penal contemporânea, prescindindo-se do livre-arbítrio para fundamentar a imposição da pena a um indivíduo concreto. Como pondera Firsch (2012), a neurociência questiona apenas uma das variantes do Direito Penal da culpabilidade, que é aquela que entende ser a função da pena uma espécie de expiação da culpabilidade do agente .

$\mathrm{Na}$ verdade, quando se trabalha com o conceito de culpabilidade, não se faz imediatamente uma referência ao livre-arbítrio como seu fundamento. Do ponto de vista formal, a culpabilidade vai estabelecer critérios de imputação individual de um fato ilícito a um autor determinado, isto é, culpabilidade é um conjunto de critérios por intermédio dos quais os seres humanos consideram suficientes para atribuir a alguém a responsabilidade pessoal pela prática de um injusto penal (MELLO, 2010b). Não depende necessariamente de um conceito ontológico ou empírico de livre-arbítrio. É certo que a neurociência e seus estudos terminam por afastar hipóteses e concepçôes indeterministas, mas é certo que a culpabilidade e os critérios de responsabilidade individual dela decorrentes náo possuem, há muito, uma concepção estritamente empírica de livre-arbítrio.

Com efeito, até defensores do finalismo não mais sustentam a ideia de culpabilidade fundada num livre-arbítrio com base puramente ontológica. Cerezo Mir (2005), por exemplo, considera que a capacidade de atuar de outro modo pode ser demonstrada empiricamente, e que a moderna antropologia consegue compreender o homem como um ser capaz de autodeterminação conforme sentido. No entanto, na sua concepção finalista são introduzidos critérios normativos e axiológicos, tendo em vista que a culpabilidade deve referir-se a um conceito de ser humano inspirado na Constituição. E esse conceito é de um homem que é pessoa, responsável e capaz de autodeterminaçấo conforme critérios normativos.

Feijóo Sanches (2012), por seu turno, pondera que determinismo e indeterminismo sáo conceitos descritivos que fazem referência ao funcionamento do mundo natural. Porém, a ideia de culpabilidade não será necessariamente modificada sua natureza tem a ver com a configuração valorativa ou normativa da sociedade, isto é, com critérios normativos de imputação.

A relevância sobre as descobertas neurocientíficas para o Direito Penal póe em xeque, na verdade, o conceito de culpabilidade como "poder atuar de outro modo" fundada na 
ideia de livre-arbítrio. Mas a culpabilidade, mesmo aquela fundada na ideia de liberdade, subsiste.

$\mathrm{Na}$ verdade, são discutíveis as consequências práticas da adoção de um modelo determinista. Há algum tempo, Jimenez de Asúa (1982, p. 63-65) já afirmava:

Desde que Enrique Ferri proclamou a morte do livre-arbítrio e da responsabilidade moral, e implantou a doutrina da responsabilidade social e legal - que levou ao projeto do Código Italiano de 1921 - se tem repetido pelos positivistas e seus seguidores que a imputabilidade penal era um conceito fadado à extinção. Proclamou Ferri que a verdadeira responsabilidade residia no fato de viver em sociedade. Porque o homem que vive nela tem de responder por todos seus atos, sem importar que o sujeito seja ou não imputável, criança ou adulto, demente ou são de espírito. [...] Os positivistas proclamaram responsável a criança e o demente; mas não lhes impunham uma pena, senão os submetiam a um tratamento educativo ou os internavam em um estabelecimento psiquiátrico. Isto mesmo proclamaram também os clássicos, apesar de considerá-los irresponsáveis.”․

Percebe-se, pois, que mudam as etiquetas, mas a verdade é uma só: mesmo quando o determinismo alcançou os píncaros de popularidade no Século XIX, havia tratamento penal diferenciado para adultos e crianças; para pessoas consideradas mentalmente saudáveis e enfermos mentais. A neurociência trará uma proposta de tratamento diferenciado?

Nesse ponto, parece acertado o posicionamento de Hirsch (2013): a negativa de responsabilidade pessoal e a promoçáo de um Direito Penal puramente preventivo provocaria um efeito dominó, pois a ausência de liberdade humana acarreta a ausência de liberdade do juiz que julga, do legislador que legisla, de modo que a irresponsabilidade se defrontaria com a irresponsabilidade, de tal sorte que o ideal de liberdade e os direitos dela recorrentes cairiam por terra. Deste modo, conclui que a problemática sobre determinismo ou indterminismo, sobretudo no que tange ao problema da culpabilidade, deve ser resolvido normativamente.

Não há consenso sobre a existência efetiva do livre-arbítrio, nem tampouco sobre as possibilidades de demonstração empírica da liberdade. Hirsch (1999), um defensor da ideia da liberdade humana, considera, inclusive, que as ciências naturais não conseguiram

6 No original: "Desde que Enrique Ferri proclamó la muerte del libre albedrio y de la responsabilidad moral, e implantó la doctrina de la responsabilidad social y legal -que llevó al proyecto de Código italiano de 1921-, se ha viniendo repitiendo por los positivistas y sus seguidores que la imputabilidad penal era un concepto llamado a extinción. Proclamó Ferri, que la verdadera responsabilidad radicaba en el hecho de vivir en sociedad. Porque el hombre vive en ella ha de responder de todo sus actos, sin importar que el sujeto sea o no imputable, niño o adulto, demente o sano de espiritu. [...] Los positivistas proclamaban responsable al niño y al demente; pero, no les imponian una pena, sino que los sometian a un tratamiento educativo o los internaban en un establecimiento psiquiátrico. Eso mismo proclamaron también los clásicos, a pesar de estimarles irresponsables. (ASÚA, 1982, p. 63-65). 
comprovar empiricamente o livre-arbítrio humano, e tampouco há perspectiva de que a referida prova venha a ser obtida no futuro.

No entanto, se há dúvidas razoáveis sobre a liberdade individual, no plano empírico ou filosófico, não se pode negar que há o reconhecimento de um direito fundamental de liberdade do gênero humano, direito este que é reconhecido pela ordem jurídica e compreende uma visão de ser humano construída historicamente e solidificada pela secularização e laicização do Estado de Direito. O ser humano é concebido pelo direito como um ser livre, seja coletiva, seja individualmente. E essa concepção não parece ser mera outorga do Direito positivo. Trata-se de um reflexo do modo com o qual o homem enxerga a si mesmo, e seria difícil conceber uma ordem jurídica que não reconheça, em maior ou menor grau, a liberdade como direito fundamental.

Não se pode deixar de reconhecer que o moderno Estado Constitucional reflete uma visão de ser humano livre, e que a democracia moderna pressupóe o exercício individual e coletivo do direito de liberdade, sem o qual não é possível conceber a dignidade humana.

As dificuldades práticas para se comprovar empiricamente o "poder atuar de outro modo" não implicam, necessariamente, a aceitação de uma postura determinista, nem tampouco representam a negação de um modelo de culpabilidade alicerçado na liberdade humana.

Livre-arbítrio e liberdade são conceitos distintos. O livre-arbítrio, como conceito filosófico, não se confunde com o conceito normativo que significa liberdade.

A necessidade de individualizar e pessoalizar a imputação a partir da culpabilidade traz evidentes problemas para uma concepção determinista, negadora de uma ideia de liberdade. Com efeito, é de manifesta ineficácia - inclusive preventiva - ameaçar e punir alguém por um fato previamente determinado por fatores causais, sem que houvesse possibilidades de atuação alternativa. Ferrajoli (2002) , nesse aspecto, assevera que um dos aspectos mais importantes do princípio da culpabilidade é que as condutas culpáveis são as únicas que podem ser lógica e sensatamente proibidas, pois se não houvesse alternativas de observar ou violar as normas penais incriminadoras, não haveria sentido em proibi-las.

Perez Manzano (1990, p.105-106) pondera que a questão da liberdade não pode ser decidida de modo empírico (seja em favor do determinismo, seja a favor do indeterminismo), por duas razóes: 1) a liberdade (assim como a dignidade ou a igualdade), não são características humanas que se possam constatar como a cor dos olhos, pois "[...] as Constituiçóes configuram uma imagem do homem conforme determinadas características, não porque não sejam incontestáveis no mundo físico, mas sim porque tratar o homem em razão desses atributos se considera valorativamente positivo "; 2) a liberdade estudada por métodos

7 No original: "Las constituciones configuran uma imagen del hombre conforme a determinadas caracteristicas, no porque no sean incontestales enel mundo físico, sino porque tratar al hombre em función de estos atributos se considera valorativamente positivo." (PÉREZ MANZANO, 1990 p.105). 
empíricos leva a resultados contraditórios, porque uma análise empírica retrospectiva da liberdade conduz ao determinismo, pois se trata de determinar as causas que levaram o sujeito a agir desta ou daquela maneira (que serão apenas aquelas, e não outras), e uma análise prospectiva conduz ao indeterminismo, pois não será possível fazer uma antevisão do futuro acerca de uma conduta individual.

Se não há perspectiva de resolver de maneira definitiva a questão empírica da liberdade, deve-se analisá-la de acordo com a metodologia jurídica, a partir da perspectiva de homem prevista na Constituição. A liberdade, assim como a dignidade, não são conceitos pertencentes ao mundo físico, mas sim do mundo valorativo; não pertencem ao ser, mas ao dever-ser e, por isso, não se sujeitam a critérios de causalidade, mas de imputação.

A liberdade, se existe ou não no plano ontológico, é uma questão de alta indagação sobre a qual ainda não há resposta. Mas o direito à liberdade existe. É a liberdade um bem jurídico-penal protegido através de normas penais; é a perda da liberdade a consequência jurídica mais frequente imposta ao condenado pela prática da infração penal; a Constituição reconhece a liberdade como um dos princípios e garantias fundamentais; é pela liberdade que se luta quando o homem se vê oprimido pela violência ou pelo arbítrio; o sofrimento e a vulnerabilidade humana quando há perda de liberdade são facilmente perceptíveis.

No aspecto, Hirsch (2013) considera que a ciência jurídica, não sendo ciência natural, deve orientar-se segundo as manifestaçóes da vida social. E como o Direito deve servir ao homem, deve aproveitar a visáo que o homem tem de si mesmo, sob pena de cair no vazio. O ser humano sente-se fundamentalmente livre, e esse é o ponto decisivo. Esta visão não significa que o homem não esteja sujeito a pressôes ou coações; contudo, a experiência mostra que o ser humano é capaz de resistir a fortes pressóes externas, à qual corresponde uma ideia geral de que há um âmbito de livre determinação. Desta maneira o homem se vê e se define como um ser livre e responsável, e é por esse ideal de liberdade que se estabelece uma luta permanente do ser humano.

E é sobre esse alicerce que se constrói a culpabilidade. A autonomia da pessoa, não como uma capacidade pré-social ou pré-jurídica de todo sujeito racional, senão um princípio organizativo dentro de um sistema de liberdades configurado como Estado de Direito (SÁNCHEZ, 2012).

Por isso, mesmo que não exista empiricamente a chamada liberdade, o homem é visto juridicamente como ser livre; existe uma ideia jurídica de liberdade sobre a qual se ergueram princípios cardeais do Estado de Direito. Esta concepção implica reconhecer que o homem, em determinadas situaçóes e circunstâncias, cometeu o delito quando tinha liberdade para não fazê-lo. Quando não existe a referida liberdade, não deve haver culpabilidade, e, por consequência, atribuição de pena. Roxin (2003, p. 803), que se posiciona 
de maneira manifestamente agnóstica sobre a existência ou não do livre-arbítrio, reconhece que a liberdade humana é uma regra do jogo social, cujo valor jurídico independe do problema da liberdade discutido pela teoria do conhecimento ou pelas ciências naturais:

Nós nos sentimos autorizados à 'asserção normativa' de que uma pessoa cuja capacidade psíquica de controle em uma determinada situação (ainda) está em ordem também pode atuar livremente, porque a autocompreensão natural do ser humano normal se baseia nesta consciência de liberdade e porque uma ordenação razoável da vida humana em sociedade não é possível sem a concessão recíproca de liberdade. Existe portanto um acordo que o Direito Penal deve partir do livre-arbítrio, ainda que o mesmo náo possa ser exatamente demonstrado.

Portanto, a neurociência não decretou o fim do Direito penal da culpabilidade, nem conseguiu eliminar a ideia de liberdade como construção normativa. A imagem que o homem tem de si mesmo como alguém que que atua com consciência e vontade pode (ou não) ser uma ilusão. Mas é uma ideia qu corresponde aos critérios socialmente tidos como racionais para aferição de responsabilidade individual. A neurociência pode, ao revés, ampliar seu caráter garantidor quando conseguir demonstrar que determinadas situaçóes, tidas como livres pelos critérios normativos da ordem jurídica, não o são. Todavia, decretar o fim da liberdade e como "efeito dominó" toda a construção do Direito Penal da culpabilidade, no mínimo, consiste numa posição precipitada

\section{Conclusões}

Não há ainda consenso - e talvez jamais haja - sobre a existência ou não da liberdade, no plano ontológico. Mas não há dúvida sobre a existência do direito à liberdade. A Constituição reconhece a liberdade como um dos princípios e garantias fundamentais, é privativa de liberdade a principal resposta 'penal ao crime. É pela liberdade que se luta quando o homem se vê oprimido pela violência ou pelo arbítrio; o sofrimento e a vulnerabilidade humana quando há perda de liberdade são facilmente perceptíveis.

Obviamente, os estudos da neurociência podem ser extremamente úteis para aferição sobre busca de fundamentos para a imposição da pena a um indivíduo concreto e estabelecer critérios para considerar alguém culpável ou não. Não é função do Direito Penal rechaçar liminarmente os conhecimentos das ciências naturais sobre o objeto daquilo que se chama de culpabilidade. Ao revés, a história tem demonstrado que por diversas vezes que os juristas se valeram do conhecimento científico vigente para fundamentar determinadas concepçóes acerca da conduta humana.

No entanto, liberdade e livre-arbítrio são conceitos distintos. A visão do homem como ser livre independe da comprovação empírica do livre-arbitrio, pois, ainda que seja 
uma ficção, é na ideia de liberdade que se constroem princípios cardeais do Estado de Direito. Esta concepção implica reconhecer que o homem, em determinadas situaçóes e circunstâncias, cometeu o delito quando tinha liberdade para não fazê-lo. Quando não existe a referida liberdade, não deve haver culpabilidade, e, por consequência, atribuição de pena.

Provar empiricamente a existência do livre-arbítrio é tão difícil quanto provar a existência do amor ou da felicidade. Não é possível provar empiricamente que alguém ama ou que alguém é feliz, mas o certo é que o homem se vê como um sujeito capaz de amar e de ser feliz, assim como o ser humano se enxerga como alguém dotado de possibilidades de escolha, e com base nestas possibilidades deve pautar sua vida como homem livre.

Somente é possível conceber e estruturar a responsabilidade penal a partir do juízo de culpabilidade caso se admita, como verdadeiro pressuposto sine qua non, um âmbito de liberdade ao indivíduo. Este âmbito de liberdade permite que a culpabilidade cumpra suas missóes mais importantes na esfera jurídico-penal: permite que se estabeleça um limite à potestade punitiva do Estado; consegue fixar um juízo individuzlizador e subjetivo da imputação (em face do injusto penal); e possibilita estabelecer critérios normativos e valorativos no juízo de imputaçáo, sem que se recorra ao caráter mortalizante das noçóes de censura e reprovação.

Os ordenamentos jurídicos de um modo geral, desde que adotaram as garantias fundamentais próprias do liberalismo político, buscaram assegurar ao indivíduo uma esfera de liberdade, que implica, no âmbito penal, assegurar direitos fundamentais de liberdade individual, possibilitando ao indivíduo autonomia ética e jurídica, livre iniciativa, garantindo a liberdade de ser e de agir, limitada pela proteção a bens jurídicos fundamentais individuais e coletivos. Para assegurar tal liberdade, emergiram princípios como o da legalidade e os subprincípios dela decorrentes (irretroatividade, taxatividade, etc.). Se um ordenamento jurídico-penal parte da imagem de uma pessoa livre, esta concepção supóe, sem que tenha que ser provado positivamente, que há pessoas que podem decidir-se livremente.

\section{Referências}

ASÚA, Luis Jimenez de. Psicoanálisis criminal. 6. ed. Buenos Aires: Depalma, 1982.

BARATTA, Alessandro. Integración-Prevención: una "nueva" fundamentación de la pena dentro de la Teoría Sistémica. En Revista Doctrina Penal, n. 29, ano 8, Buenos Aires, 1985 .

BETTIOL, Giuseppe. Direito Penal, v. 1. Trad. Paulo José da Costa Jr. e Alberto da Silva Franco. 2a Ed. São Paulo, Editora Revista dos Tribunais, 1977. 
BIRMAN, Joel, estilo e modernidade em psicanálise, São Paulo, Ed. 34, 1997.

BUSATO, Paulo César. Apontamentos sobre o dilema da culpabilidade penal. In Revista Liberdades - n. ${ }^{\circ}$ 8-setembro-dezembro de 2011. São Paulo, IBCCRIM, 2011.

CARBONELL MATEU, Juan Carlos. Derecho Penal: concepto y principios constitucionales. 2 ed. Valencia: Tiranto lo Blanch, 1996.

CEREZO MIR, José. Curso de Derecho Penal Español-Parte General, v. III - Teoría juridica do delito/2, 5. reimpr. Madrid: Tecnos, 2005.

COBO DEL ROSAL, Manuel; VIVES ANTÓN, Tomás S. Derecho Penal, parte general. 5. ed. Valencia: Tirant lo Blanch, 1999.

COIMBRA, Regis Antonio, Descrição da liberdade numa perspectiva determinista: Aristóteles no contexto da ciência moderna. Veritas: Revista Trimestral de Filosofia e Ciências Humanas da PUC-RS. v. 43, n. 172. Porto Alegre, PUC, 1998.

CÓRDOBA RODA, Juan. Culpabilidad y Pena. Barcelona: Bosch, 1977.

COUSO SALAS, Jaime. Fundamentos del Derecho Penal de Culpabilidad: historia, teoria y metodología. Valencia: Tirant Lo Blanch, 2006.

CRESPO, Eduardo Demetrio. "Compatibilismo humanista": una propuesta de conciliación e neurociencias y derecho penal. IN CRESPO, Eduardo Demetrio; CALATAYUD, Manuel Maroto. Neurociencias y Derecho Penal nuevas perspectivas en el ámbito de la culpabilidad y tratamiento jurídico-penal de la peligrosidad. Montivideo- Buenos Aires, 2013.

DAMÁSIO, Antonio R., O erro de Descartes: Emoção, razão e o cérebro humano. Trad. Dora Vicente e Regina Segurado. 3. Ed. São Paulo, Companhia das Letras, 2012.

DENNET, Daniel, La libertad de acción: un análisis de la exigencia de libre albedrio, 2.ed. Barcelona, Gedisa, 2000.

EAGLEMAN, David, Incógnito - As vidas secretas do cérebro. Trad. Ryta Vinagre, Rio de Janeiro, Rocco, 2012.

FERRAJOLI, Luigi, Direito e Razão - Teoria do Garantismo Penal. Trd. Ana Paula Zomer e outros, São Paulo: Revista dos Tribunais, 2002.

FIGUEIREDO DIAS, Jorge de. Direito Penal; Parte Geral: t.1. questóes fundamentais: a doutrina geral do crime. São Paulo: Revista dos Tribunais; Portugal: Coimbra Editora, 2007.

FRANK, Reinhard. Sobre la estructura del concepto de culpabilidad. 2. Reimpr. Buenos Aires: Editorial B de F, 2004.

FREUD, Sigmund. (1914) Sobre o narcisismo uma introdução. In:FREUD, Sigmund. Obras completas. Rio de Janeiro: Imago, 1996, vol. XIV. 
FRISCH, Wolfgang, sobre el futuro del derecho penal de la culpabilidad. In: SÁNCHEZ, Bernardo José Feijoo (coord.), Derecho Penal de La Culpabilidad y Neurociencias. Pamplona: Civitas/Thomson Reuters, 2012.

GIMBERNAT ORDEIG, Enrique. ¿Tiene un futuro la dogmática penal? In: Problemas actuales de las ciencias penales y la filosofia del derecho: en homenaje al profesor Luis Jiménez de Asúa. Buenos Aires: Pannedille, 1970.

GOLDSCHMIDT, James. La concepción normativa de la culpabilidad. Trad. Ricardo C. Nuñez, 2.ed., Buenos Aires: Editorial B de F, 2002.

GRACIA MARTÍN, Luis. El finalismo como método sintético real-normativo para la construcción de la teoría del delito. Revista Electrónica de Ciencia Penal y Criminologia (en línea). Disponible en Internet: http://criminet.ugr.es/recpc/06/recpc06-07. pdf. , 2004, Acesso em 06/11/2013.

GÜNTHER, Klaus. A culpabilidade no Direito Penal atual e no futuro. Trad. Juarez Tavares. Revista Brasileira de Ciências Criminais, ano 6, n. 24 , São Paulo: Revista dos Tribunais, 1998.

HASSEMER, Winfried. História das Idéias Penais na Alemanha do Pós-Guerra.Revista Brasileira de Ciências Criminais, ano 2, n. 06, São Paulo: Editora Revista dos Tribunais, 1994.

HIRSCH, Hans Joachim, Acerca de la actual discusión alemana sobre liberta de voluntady Derecho Penal. IN CRESPO, Eduardo Demetrio; CALATAYUD, Manuel Maroto. Neurociencias y Derecho Penal nuevas perspectivas en el ámbito de la culpabilidad y tratamiento juridico-penal de la peligrosidad. Montivideo-Buenos Aires, 2013.

HIRSCH, Hans Joachim. El principio de culpabilidad y su función en el derecho penal. En: Derecho Penal: obras completas. Buenos Aires : Rubinzal-Culzoni, 1999.

LIBET, Benjamin, Mind and Time: The Temporal Factor in. Consciousness, Harvard University Press, Cambridge 2004.

MELLO, Sebástian Borges de Albuquerque, A evolução do conceito de culpabilidade e a moderna doutrina alemã, in: Ciências Penais - Revista da Associação Brasileira de Professores de Ciências Penais, v. 12, São Paulo: Revista dos Tribunais, 2010a.

MELLO, Sebástian Borges de Albuquerque. O conceito material de culpabilidade. Salvador, Juspodivm, 2010b.

MINAHIM, Maria Auxiliadora, COELHO, Yuri Carneiro, A estrutura ontológica das coisas como recurso garantidor no Direito Penal. In PRADO, Luiz Régis (Coord). Direito Penal contemporâneo: estudos em homenagem ao professor Cerezo Mir. São Paulo: Revista dos Tribunais, p. 101-109, 2007. 
MIR PUIG, Santiago. Derecho Penal- Parte General, 7ed. Buenos Aires: Editorial B de F. 2004.

MONTES HUAPAYA, Sandro, El principio de culpabilidad como concepto político criminal dentro un Estado de Derecho, social y democrático. En: Derecho Penal Online (revista electrónica de doctrina y jurisprudencia en línea). Año 2007. Disponible en Internet: http:// www.derechopenalonline.com). Acesso em 11/11/2007.

PÉREZ MANZANO, Mercedes. Culpabilidad y Prevención; las teorías de la prevención general positiva en la fundamentación de la imputación subjetiva y de la pena. Madrid: Universidad Autónoma de Madrid, 1990.

POPPER, Karl. De nuvens e relógios. In: Conhecimento Objetivo. Belo Horizonte: Itatiaia, 1975.

QUEIROZ, Paulo. Curso de Direito Penal Parte Geral. 9a Edição. Editora jusPODIVM: 2013.

ROXIN, Claus. Derecho Penal: Parte General. Tomo I: Fundamentos. La Estructura de la Teoría del Delito. Trad. Diego-Manuel Luzón Peña, Miguel Díaz y Garcia Conlledo e Javier de Vicente Remesal, Madrid: Thomsom-Civitas, 2003, p. 799.

RUBIA, Francisco J. Neurociência y Libertad. In CRESPO, Eduardo Demetrio; CALATAYUD, Manuel Maroto. Neurociencias y Derecho Penal nuevas perspectivas em el âmbito de la culpabilidad y tratamiento jurídico-penal de la peligrosidad.MontivideoBuenos Aires, 2013.

SÁNCHEZ, Bernardo José Feijoo.Derecho Penaly Neurociencias. Una relación tormentosa? In: SÁNCHEZ, Bernardo José Feijoo, Derecho Penal de La Culpabilidad y Neurociencias. Pamplona: Civitas/Thomson Reuters, 2012.

STAECHELIN, Gregor. ¿Es compatible la "prohibición de infraprotección” con una concepción liberal del derecho penal? In: ROMEO CASABONA, Carlos María (coord), La insostenible situación del Derecho Penal. Granada: Comares, 2000.

WELZEL, Hans. El nuevo sistema del derecho penal: una introducción a la doctrina de la acción finalista. Trad. José Cerezo Mir. Buenos Aires: Editorial B de F, 2004.

WELZEL, Hans. Reflexiones sobre el libre albedrio. In: WELZEL, Hans. Estudios de Filosofia del Derecho y Derecho Penal, Buenos Aires: Editorial B de F, 2004. 